\title{
GROWTH AND PHYSIOLOGY OF CITRUS ROOTSTOCKS UNDER SALT STRESS
}

\author{
CRESCIMENTO E FISIOLOGIA DE PORTA-ENXERTOS DE CITROS SOB \\ ESTRESSE SALINO
}

\author{
Francisco Vaniés da Silva SÁ ${ }^{1^{*}}$; Marcos Eric Barbosa BRITO ${ }^{2,8}$; \\ Rômulo Carantino Lucena MOREIRA ${ }^{3}$; Luderlândio de Andrade SILVA ${ }^{3}$; \\ Walter dos Santos SOARES FILHO ${ }^{4,8}$; Lizaiane Cardoso de FIGUEIREDO ${ }^{5}$; \\ Hans Raj GHEYI ${ }^{6,8}$; Pedro Dantas FERNANDES ${ }^{7,8}$;
}

1. Doctor in Agricultural Engineering, Postdoctoral Fellow of the National Postdoctoral Program, Federal Rural Semi-Arid University, Mossoró, RN, Brazil. vanies_agronomia@ hotmail.com; 2. Doctor in Agricultural Engineering, Teacher, Federal University of Sergipe, Campus do Sertão; Nossa Senhora da Glória, SE, Brazil; 3. Doctorate in Agricultural Engineering, Federal University of Campina Grande - UFCG, Campina Grande, PB, Brazil; 4. Doctor in Agronomy, Researcher A of Embrapa Cassava \& Fruits, Cruz das Almas, BA, Brazil; 5. Master's degree in Tropical Horticulture, UFCG, Pombal, PB, Brazil; 6. Doctor in Agronomic Sciences., Visiting Teacher, Federal University of Recôncavo Baiano - UFRB, Cruz das Almas, BA, Brazil; 7. Doctor in Soil and Plant Nutrition, Visiting Teacher, UFCG, Campina Grande, PB, Brazil; 8. CNPq PQ scholarship holder.

\begin{abstract}
In order to study the growth and physiology of citrus rootstocks under saline water irrigation, during formation of rootstocks, an assay was carried out in a factorial scheme, $2 \times 6$, corresponding to two levels of salinity of the nutrient solution: 0.3 and $4.0 \mathrm{dS} \mathrm{m}^{-1}$ and six genotypes provided by the Citrus Breeding Program of Embrapa Cassava \& Fruits-CBP, distributed in randomized block design with three replications. The genotypes were: 1. 'Santa Cruz Rangpur' lime (SCRL) (Citrus limonia Osbeck), 2. 'Florida Rough' lemon (FRL) (Citrus jambhiri Lush.), 3. 'Volkamer' lemon (VKL) (C. volkameriana V. Ten. \&Pasq.), 4. CSM x SWC- 028, 5. CSM x SWC- 033 and 6.CSM x SWC-041, the last three hybrids of common 'Sunki' mandarin (CSM) [C.sunki (Hayata) hort. ex Tanaka] with 'Swingle' citrumelo (SWC) [C. paradisi Macfad. x Poncirus trifoliata (L.) Raf.]. Nucellar plants from these genotypes were grown in alternative hydroponic system, using Leonard jars. Application of nutrient solution made with saline water started from 90 days after sowing until 120 days, when the growth and physiology parameters of plants were evaluated. Salt stress influenced the growth and physiological parameters in all genotypes. Salt stress did not influence the chlorophyll $a$ fluorescence in the genotypes VKL and CSM x SWC- 041, indicating no damage to the photosynthetic apparatus. The CSM x SWC- 041, 'Santa Cruz Rangpur' lime, 'Florida Rough' lemon and 'Volkamer' lemon are the more tolerant genotypes to salinity based on growth rate.
\end{abstract}

KEYWORDS: Citrus spp. Chlorophyll fluorescence. Growth rate. Gas exchange. Salinity.

\section{INTRODUCTION}

The citrus crop has a prominent place in Brazilian agriculture due to juice export value and, not least important, for its social relevance, generating income for a large number of citrus growers and a great number of jobs (SHAFER et al., 2008; SOUZA et al., 2013). Accounting for more than $28.4 \%$ of the fruits produced in the world, the Brazilian Citrus Industry is mainly represented by orange (762,765 ha), tangerine (52,023 ha), acid lime and lemon (48,244 ha), resulting in a planted area of approximately 863,032 ha, with an average yield of 20,180,507 $\mathrm{t}$ year $^{-1}$ (IBGE, 2014). The Brazilian Southeast region is the biggest producer of citrus, representing $78.9 \%\left(15,915,575 \mathrm{t} \mathrm{year}^{-1}\right)$ of the national production, followed by the Northeast region, which accounts for $10.2 \%(2,054,791 \mathrm{t}$ year $\left.{ }^{1}\right)$ of the national production.

In northeastern Brazil, the socioeconomic importance of citrus crop is undeniable in view of the creation of jobs and income, especially in the states of Bahia, Sergipe, major producers in the region, and Paraiba, which is prominent in the production of tangerine (IBGE, 2014). However, the productivity of the region is low, approximately $17 \mathrm{t}$ $\mathrm{ha}^{-1}$, when compared to the potential of this crop, which can reach up to $40 \mathrm{t} \mathrm{ha}^{-1}$, as observed from statistics from other countries (FAO, 2013).

This situation may be related to the natural drought that lasts more than six months each year, coinciding generally with high temperatures. It results in the need to use sources of water for irrigation, whit high concentration of salts (MEDEIROS et al., 2010). This is a condition that contributes the most to reduced growth and physiological disorders in plants (BRITO et al., 2008; FERNANDES et al., 2011; NASCIMENTO et al., 2012; SILVA et al., 2012; BRITO et al., 2014a; BRITO et al., 2014b), especially citrus plants, considered sensitive to salinity (SYVERTSEN; GARCIA-SANCHEZ, 2014). 
One of the key factors for the development of citrus is the rootstock because it is the basis of orchards and affect all the planting cycle (RESENDE et al., 2010). However, the rootstock diversity in Brazilian orchards is low, with a predominance of 'Rangpur' lime (Citrus limonia Osbeck), a genotype susceptible to citrus sudden death (POMPEU JUNIOR; BLUMER; RESENDE,2013). As alternatives to this rootstock, 'Volkamer' lemon (C. volkameriana V. Ten. \& Pasq.), Cleopatra mandarin (C. reshnihort. ex Tanaka), 'Sunki' mandarin [C.sunki (Hayata) hort. ex Tanaka], trifoliate orange [Poncirus trifoliata (L.) Raf.] and 'Swingle' citrumelo (C. paradisi Macfad. x $P$. trifoliata) (FRANCO et al., 2007) can be mentioned. However, there is need to have new materials with tolerance to other factors, like abiotic stress.

Thus, the challenge to expand irrigated agriculture in regions with scarcity of water is concentrated on selecting genetic materials with a satisfactory production; that is, a production equivalent to that obtained when there are no physiological disorders in the production system from irrigation with a high-salt content water, using the ability to adapt to salt stress (BRITO et al., 2014a; Silva et al., 2014). Importantly, the main mechanisms of tolerance to salt in citrus plants are related to the exclusion of salts by roots, to the accumulation of salts in old leaves and to the reduction of transpiration capacity (BALAL et al., 2012; RODRIGUEZ-GAMIR et al., 2012; GONZÁLEZ; SYVERTSEN; ETXEBERRIA, 2012; SILVA et al., 2014).

For this, it is necessary to consider a priori new genotypes in the stage of rootstock formation by studying growth and physiological characteristics. In this sense, this work was planned in order to evaluate the growth and physiological aspects of six citrus rootstocks, including traditional varieties and hybrids of 'Sunki' mandarin with
'Swingle' citrumelo, under different levels of irrigation water salinity in the stage of rootstock formation.

\section{MATERIAL E METHODS}

The experimentit was conducted from March to July of 2013, in protected environment (greenhouse) of Center of Science and Technology Agrifood- CCTA, of the Federal University of Campina Grande - UFCG, in the municipality of Pombal, Paraiba state, with geographic coordinate $6^{\circ} 47^{\prime} 20^{\prime \prime} \mathrm{S}, 37^{\circ} 48^{\prime} 01^{\prime \prime} \mathrm{W}$, and average elevation of $184 \mathrm{~m}$.

Treatments were distributed in randomized block design in a factorial scheme, $2 \times 6$. The factors were related to two levels of water salinity used to prepare the nutrient solutions: $S_{1}=0.3$ and $\mathrm{S}_{2}=4.0 \mathrm{dS} \mathrm{m} \mathrm{m}^{-1}$; and six citrus rootstocks provided by the Citrus Breeding Program of Embrapa Cassava \& Fruits - CBP. These genotypes were: 1. 'Santa Cruz Rangpur' lime (SCRL), 2. 'Florida Rough' lemon (FRL) (C. jambhiri Lush.), 3. 'Volkamer' lemon (VKL), 4. CSM x SWC - 028, 5. CSM x SWC - 033 and 6. CSM x SWC - 041, the last three hybrids of common 'Sunki' mandarin (CSM) with 'Swingle' citrumelo (SWC). Treatments were distributed in three blocks with four plants per plot in order to control radiation incidence into the protected environment.

The different genotypes were sown and grown inrecipients with $1.5 \mathrm{~L}$ capacity, with coconut fiber, washed in water current, as substrate, in order to ensure that there was no salt and nutrients present in the material. Nutrient solutions following Hoagland and Arnon (1950) recommendations were prepared, with additional $25 \%$ iron EDTA, in order to meet genotypes nutritional needs (Table 1), as observed in preliminary test.

Table 1. Concentration of nutrients in the nutrient solution for hydroponic cultivation of citrus (adapted from HOAGLAND; ARNON, 1950).

\begin{tabular}{|c|c|c|c|c|c|c|c|c|c|c|c|}
\hline \multicolumn{12}{|c|}{ Nutrient content } \\
\hline $\mathrm{N}$ & $\mathrm{P}$ & $\mathrm{K}$ & $\mathrm{Ca}$ & $\mathrm{Mg}$ & $\mathrm{S}$ & $\mathrm{Fe}$ & $\mathrm{Mn}$ & B & $\mathrm{Cu}$ & $\mathrm{Zn}$ & $\mathrm{Mo}$ \\
\hline & & & & & & $\ldots .(\mathrm{m}$ & $\left.\mathrm{L}^{-1}\right) \ldots$ & & & & \\
\hline 15 & 1 & 6 & 5 & 2 & 2 & 0.0625 & 0.01 & 0.05 & 0.003 & 0.0008 & 0.001 \\
\hline
\end{tabular}

Rootstocks were cultivated in recipients Leonard pots fitted with Pet bottles (SILVA et al., 2014). Upper part of pot was filled with $1.5 \mathrm{~L}$ of the substrate, and the bottom part was filled with Hoagland $^{\circledR}$ nutrient solution (HOAGLAND; ARNON, 1950) under continuous flow.
After Leonard pots preparation, they were envolved with double sided plastic, in order to reduce the evaporation losses, which was checked daily and, when necessary, supplemented according to treatment, to ensure that the substrate would 
always be with moisture content close to field capacity.

Direct sowing in Leonard pots was conducted, and after germination, when seedlings had three or more true leaves, thinning was carried out, leaving only one nucellar plant per pot. Every precaution to pest control monitoring and prevention were adopted, as recommended in citrus seedlings production.

Nutrient solutions mixture water were prepared at an equivalent ratio of 7:2:1 $\mathrm{Na}, \mathrm{Ca}$ and $\mathrm{Mg}$, using $\mathrm{NaCl}, \mathrm{CaCl}_{2} \cdot 2 \mathrm{H}_{2} \mathrm{O}$ and $\mathrm{MgCl}_{2} \cdot 6 \mathrm{H}_{2} \mathrm{O}$ salts, respectively. Preparation of solutions with different electrical conductivities (EC) was performed by addition of salts to the water until reaching the desired EC level, with values being measured through a previously calibrated portable conductivity meter adjusted to a temperature of 25 ${ }^{\circ} \mathrm{C}$.

The nutrient solution was prepared with distilled water and had $2.3 \mathrm{dS} \mathrm{m}^{-1}$ electrical conductivity, with the addition of $0.3 \mathrm{dS} \mathrm{m}^{-1}$ and 4.0 $\mathrm{dS} \mathrm{m} \mathrm{m}^{-1}$ salinethe available solutions to plants had electrical conductivity of 2.6 and $6.3 \mathrm{dS} \mathrm{m} \mathrm{m}^{-1}$, respectively.

Tested water salinity levels were established through salinity threshold $\left(2 \mathrm{dS} \mathrm{m}^{-1}\right)$, with a level below and other above salinity threshold being established for citrus species, as described by Singh et al. (2003).

According to the methodology proposed by Benincasa (2003), absolute and relative growth rates in height were determined by equations 1 and 2 , stem diameter by Equations 3 and 4, and the number of leaves by Equations 5 and 6, respectively, through stem diameter growth, height and rootstocks leaf production data before saline treatments application, at 90 days after sowing, and with last growth analysis data, which was carried out 120 days after sowing. The last evaluation was carried out 120 days after sowing, as some rootstocks already had satisfactory diameters for grafting.

$$
\begin{aligned}
& \text { AGRH }=\frac{h 2-h 1}{t 2-t 1} \\
& R G R H=\frac{\operatorname{lnh} 2-\ln h 1}{t 2-t 1}
\end{aligned}
$$

Where: $\mathrm{AGRH}=$ absolute growth rate in plant height $\left(\mathrm{cm} \mathrm{day}^{-1}\right) ; \mathrm{h} 1=$ plant height at time $\mathrm{t} 1(\mathrm{~cm})$; $\mathrm{h} 2=$ plant height at time $\mathrm{t} 2(\mathrm{~cm}) ; \mathrm{RGRH}=$ relative growth rate in plant height $\left(\mathrm{cm} \mathrm{cm}^{-1}\right.$ day $\left.^{-1}\right)$; $\mathrm{Ln}=$ natural logarithm.

$$
\begin{aligned}
& A G R S D=\frac{s d 2-s d 1}{t 2-t 1} \\
& R G R S D=\frac{\ln s d 2-\ln s d 1}{t 2-t 1}
\end{aligned}
$$

Where: AGRSD = absolute growth rate in stem diameter $\left(\mathrm{mm}\right.$ day $\left.^{-1}\right)$; sd $1=$ plant stem diameter at time $\mathrm{t} 1(\mathrm{~mm}) ; \mathrm{sd} 2=$ plant stem diameter at time $\mathrm{t} 2$ $(\mathrm{mm}) ;$ RGRSD $=$ relative growth rate in stem diameter $\left(\mathrm{mm} \mathrm{mm}^{-1}\right.$ day $\left.^{-1}\right) ; \mathrm{Ln}=$ natural logarithm.

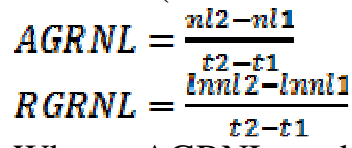

Where: $A G R N=$ absolute growth rate in number of leaves (leaves day $^{-1}$ ); nll = number of leaves at time $\mathrm{t} 1(\mathrm{~cm}) ; \mathrm{nl} 2=$ number of leaves at time $\mathrm{t} 2$ $(\mathrm{cm}) ;$ RGRNL = relative growth rate in number of leaves (leaf-leaf ${ }^{-1}$ day $^{-1}$ ); ln = natural logarithm.

At 120 days after growth measurement, the different genotypes were assessed under salt stress physiological establishment, measuring $\mathrm{CO}_{2}$ assimilation $(A)\left(\mu \mathrm{mol} \mathrm{m} \mathrm{m}^{-2} \mathrm{~s}^{-1}\right)$, transpiration $(E)$ $\left(\mathrm{H}_{2} \mathrm{O} \mathrm{m}^{-2} \mathrm{~s}^{-1} \mathrm{mmol}\right)$, stomatal conductance $(g s)\left(\mathrm{H}_{2} \mathrm{O}\right.$ $\mathrm{m}^{-2} \mathrm{~s}^{-1} \mathrm{~mol}$ ) and $\mathrm{CO}_{2}$ internal concentration $(\mathrm{Ci})$ rates in the first mature leaf counted from the apex. With these data, water use efficiency (WUE) $(A / E)$

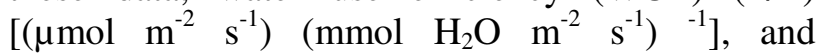
carboxylation instantaneous efficiency $(\mathrm{A} / \mathrm{C} i)$ (BRITO et al., 2012) were quantified using the "LCPro+" portable photosynthesis measuring equipment, ADC BioScientific Ltd. In these same leaves where gas exchanges were analyzed, leaf tweezers were placed and, after a $30 \mathrm{~min}$. of darkadaptation period, the following data were determined: initial fluorescence (Fo), maximum fluorescence $(\mathrm{Fm})$, variable fluorescence (Fm-Fo) and photosystem II quantum efficiency (Fv/Fm) (MAXWELL; JOHNSON, 2000), using the PEA Hansatech equipment.

After physiological analysis measurement, plants' samples were taken in order to obtain the shoot dry matter, root dry matter and total dry matter, through plant parts partition and packaging into air greenhouse incubator at $65{ }^{\circ} \mathrm{C}$, drying the matter for $72 \mathrm{~h}$ and then weighting it on an analytical scale. Root/shoot ratio was assessed from these data through the quotient between root dry matter and shoot dry matter.

Data were assessed by analysis of variance (ANOVA). In significance cases, Scott and Knott's mean grouping test, at 5\% probability, was used for genotypes, and for each genotype the mean test was used for salinity factor (FERREIRA, 2011).

\section{RESULTS AND DISCUSSION}

The rootstock varieties Florida Rough lemon (FRL), Santa Cruz Rangpur lime (SCRL) and Volkamerlemon (VKL) had the highest growth rates 
with respect to plant height, diameter and number of leaf under saline conditions compared to the hybrids from common 'Sunki' mandarin (CSM) with 'Swingle' citrumelo (SWC) (Table 2). However, despite this greater potential of growth of the mentioned rootstock varieties, there were significant reductions in the absolute growth rates regarding height, diameter and leaf number of SCRL and VKL when subjected to the highest level of salinity (4.0 $\mathrm{dS} \mathrm{m}^{-1}$ ). Considering that salts may affect the growth of plants by ionic and/or osmotic effects according to the plants' tolerance (AL YASSIN, 2004; BALAL et al., 2012; RODRIGUEZ-GAMIR et al., 2012; BRITO et al., 2014), it can be emphasized that FRL and CSM x SWC hybrids have a greater potential of tolerance for the variables related to absolute and relative growth rates, that are considered important in stress studies (LACERDA et al., 2006).

Also regarding growth rates, an increase in the values of absolute and relative growth rates regarding plant height, number of leaf and absolute growth rate of stem diameter can be noted in relation to the genotype CSM x SWC- 028 when a nutrient solution prepared with water of higher electrical conductivity was applied. This also occurred in case of CSM x SWC- 033 and CSM x SWC- 041 for variables absolute growth rate in stem diameter (AGRSD), relative growth rate in number of leaves (RGRNL), absolute growth rate in number leaf (AGRNL), absolute growth rate in height $(\mathrm{AGRH})$ and relative growth rate in height $(\mathrm{RGRH})$ (Table 2).

Table 2. Absolute (AGRH) and relative growth rate in height (RGRH), in stem diameter (AGRSD and RGRSD), in number of leaves (AGRNL and RGRNL) for six citrus genotypes grown in two levels of water salinity.

\begin{tabular}{|c|c|c|c|c|c|c|}
\hline \multirow{3}{*}{ Genotype } & \multicolumn{6}{|c|}{ Watersalinity $\left(\mathrm{dS} \mathrm{m} \mathrm{m}^{-1}\right)$} \\
\hline & $0,3 \mathrm{dSm}^{-1}$ & $4,0 \mathrm{dSm}^{-1}$ & $0,3 \mathrm{dSm}^{-1}$ & $4,0 \mathrm{dSm}^{-1}$ & $0,3 \mathrm{dSm}^{-1}$ & $4,0 \mathrm{dSm}^{-1}$ \\
\hline & \multicolumn{2}{|l|}{$\begin{array}{l}\mathrm{AGRH}^{*} \\
\left(\mathrm{~cm} \mathrm{day}^{-1}\right)\end{array}$} & \multicolumn{2}{|c|}{$\begin{array}{l}\mathrm{RGRH}^{*} \\
\left(\mathrm{~cm} \mathrm{~cm}^{-1} \mathrm{day}^{-1}\right)\end{array}$} & \multicolumn{2}{|l|}{$\begin{array}{l}\text { AGRSD* } \\
\left(\mathrm{mm} \mathrm{day}^{-1}\right)\end{array}$} \\
\hline FRL & $0.4042 \mathrm{bA}$ & $0.3333 \mathrm{aA}$ & $0.0238 \mathrm{aB}$ & $0.0266 \mathrm{aA}$ & $0.0504 \mathrm{aA}$ & $0.0490 \mathrm{aA}$ \\
\hline SCRL & $0.7104 \mathrm{aA}$ & $0.3417 \mathrm{aB}$ & $0.0233 \mathrm{aA}$ & $0.0239 \mathrm{bA}$ & $0.0445 \mathrm{aA}$ & $0.0287 \mathrm{bB}$ \\
\hline VKL & $0.4944 \mathrm{bA}$ & $0.2528 \mathrm{aB}$ & $0.0216 \mathrm{aA}$ & $0.0180 \mathrm{cB}$ & $0.0498 \mathrm{aA}$ & $0.0319 \mathrm{bB}$ \\
\hline CSM x SWC -028 & $0.0208 \mathrm{cA}$ & $0.0324 \mathrm{bA}$ & $0.0057 \mathrm{cB}$ & $0.0144 \mathrm{dA}$ & $0.0120 \mathrm{bA}$ & $0.0197 \mathrm{cA}$ \\
\hline CSM x SWC -033 & $0.0167 \mathrm{cA}$ & $0.0167 \mathrm{bA}$ & $0.0055 \mathrm{cA}$ & $0.0051 \mathrm{fA}$ & $0.0068 \mathrm{bA}$ & $0.0126 \mathrm{dA}$ \\
\hline CSM x SWC -041 & $0.0458 \mathrm{cA}$ & $0.0625 \mathrm{bA}$ & $0.0101 \mathrm{bA}$ & $0.0106 \mathrm{eA}$ & $0.0068 \mathrm{bA}$ & $0.0059 \mathrm{dA}$ \\
\hline Genotype & \multicolumn{2}{|c|}{$\begin{array}{l}\text { RGRSD** } \\
\left(\mathrm{mm} \mathrm{mm}^{-1} \mathrm{day}^{-1}\right)\end{array}$} & $\begin{array}{l}\text { AGRNL* } \\
\text { (leafday }^{-1} \text { ) }\end{array}$ & & \multicolumn{2}{|c|}{$\begin{array}{l}\text { RGRNL* } \\
\text { (leafleaf }^{-1} \text { day }^{-1} \text { ) }\end{array}$} \\
\hline FRL & \multicolumn{2}{|l|}{$0.0174 \mathrm{a}$} & $0.1958 \mathrm{bA}$ & $0.1556 \mathrm{bA}$ & $0.0139 \mathrm{aA}$ & $0.0138 \mathrm{aA}$ \\
\hline SCRL & \multicolumn{2}{|l|}{$0.0116 \mathrm{a}$} & $0.2958 \mathrm{aA}$ & $0.2167 \mathrm{aB}$ & $0.0127 \mathrm{aA}$ & $0.0169 \mathrm{aA}$ \\
\hline VKL & \multicolumn{2}{|l|}{$0.0123 \mathrm{a}$} & $0.2667 \mathrm{aA}$ & $0.1111 \mathrm{cB}$ & $0.0162 \mathrm{aA}$ & $0.0117 \mathrm{aB}$ \\
\hline CSM x SWC - 028 & \multicolumn{2}{|l|}{$0.0088 \mathrm{~b}$} & $0.0667 \mathrm{~dB}$ & $0.1208 \mathrm{cA}$ & $0.0130 \mathrm{aA}$ & $0.0143 \mathrm{aA}$ \\
\hline CSM x SWC - 033 & \multicolumn{2}{|l|}{$0.0073 \mathrm{~b}$} & $0.0222 \mathrm{dA}$ & $0.0417 \mathrm{dA}$ & $0.0045 \mathrm{bA}$ & $0.0079 \mathrm{bA}$ \\
\hline CSM x SWC - 041 & \multicolumn{2}{|l|}{$0.0034 \mathrm{c}$} & $0.1167 \mathrm{cA}$ & $0.1083 \mathrm{cA}$ & $0.0167 \mathrm{aA}$ & $0.0132 \mathrm{aA}$ \\
\hline
\end{tabular}

$*$ and $* *=$ Interaction genotype $\mathrm{x}$ water salinity and genotype factor significant at 0.05 probability level, respectively. Means followed by different small letters indicate difference between genotypes by Skott-Knott test and by capital letters indicate difference between salinity levels by $\mathrm{F}$ test at 0.05 probability. FRL - 'Florida Rough lemon' $(C$. jambhiri), SCRL - 'Santa Cruz Rangpur' lime $(C$. limonia), VKL - Volkamer lemon (Citrus volkameriana), CSM - Common 'Sunki' mandarin (C. sunki) and SWC - 'Swingle' citrumelo (Citrus paradisi x Poncirus trifoliata).

Such increases in growth rates under saline conditions may be related to the tolerance mechanism of the progeny CSM x SWC. That it can be due some plants, under saline conditions, increase in their photosynthetic rate in order to avoid the effects of salt stress by forming secondary metabolites such as proline and glycine-betaine (TAIZ; ZAIGER, 2013), which may have stimulated the growth of these hybrids (Table 2). It is noteworthy that the increase in leaf number is proportional to the number of vacuoles for translocation of solutes (salts), which may mitigate the effects of salt stress since the accumulation of salts in the vacuole is a main tolerance mechanism of citrus (GONZÁLEZ; SYVERTSEN; ETXEBERRIA，2012; SYVERTSEN; GARCIA-SANCHEZ, 2014).

On the other hand, it should be noted that the growth rates evidenced in the hybrids CSM x SWC- 028, 033 and 041 were lower regardless of the imposed 
salinity condition. This may be characteristic of these genotypes, possibly indicating minor characteristics, that it is interesting considering the new challenges of citrus crop in face of phytosanitary problems (STUCHI; GIRARDI, 2011).

The relative growth in height and the leaf issuing of the 'Volkamer' lemon decreased when subjected to the highest level of salinity $\left(4.0 \mathrm{dS} \mathrm{m}^{-1}\right)$ (Table 2). This evidences the effect of salt stress on the growth activity of this genotype, which could be best described by studying its physiology, despite showing a higher growth even in plants irrigated with the highest level of salinity.

Considering the gas exchange of the genotypes studied, reductions in the internal concentration of $\mathrm{CO}_{2}$ in 'Santa Cruz Rungpur' lime and CSM x SWC - 041 were observed when salinity was increased from 0.3 to $4.0 \mathrm{dS} \mathrm{m}^{-1}$ (Table 3). However, no statistical difference in the other variables from SCRL was observed. Furthermore, there was an expansion of $107.1 \%$ in the $\mathrm{CO}_{2}$ assimilation rate of the genotype CSM x SWC- 041, achieving an instantaneous efficiency of carboxylation
SÁ, F. V. S. et al.

under the highest salinity $\left(4.0 \mathrm{dS} \mathrm{m}^{-1}\right)$ in relation to the lowest salinity level $\left(0.3 \mathrm{dS} \mathrm{m}^{-1}\right)$ (Table 3$)$. Also considering CSM x SWC- 041, there was an increase in water use efficiency when it was subjected to salt stress. This could be related to an increase in photosynthetic activity, promoting a greater unchanged carbon fixation in transpiration (MACHADO et al., 2005; SHIMAZAKI et al., 2007; SILVA et al., 2014). This indicates this genotype's potential to adapt to saline stress.

The reduction of the internal concentration of $\mathrm{CO}_{2}$, along with the increased $\mathrm{CO}_{2}$ assimilation rate and the instantaneous efficiency of carboxylation, indicates an increase in the activity of ribulose-1,5-bisphosphate carboxylase/oxygenase (RuBisCO) (MACHADO et al., 2005; LÓPEZ-CLIMENT et al., 2011; SILVA et al., 2014). It was possibly induced by salt stress, causing the expression of salt tolerance mechanisms such as the increase in photosynthetic efficiency and therefore flow of solute in the plant, favoring the dilution and the translocation of ions inside the plant, thereby accelerating their compartmentalization in the vacuole (SÁ et al., 2015).

Table 3. Stomatal conductance $(g s)$, transpiration $(E)$, water use efficiency (WUE), $\mathrm{CO}_{2}$ internal concentration $(\mathrm{Ci}), \mathrm{CO}_{2}$ assimilation $(\mathrm{A})$ and carboxylation instantaneous efficiency $(\mathrm{A} / \mathrm{Ci})$ for six citrus genotypes grown in two levels of salinity of the water.

\begin{tabular}{|c|c|c|c|c|c|c|}
\hline \multirow[b]{2}{*}{ Genotype } & 0,3 dS.m & $4,0 \mathrm{dS} \cdot \mathrm{m}^{-1}$ & $0,3 \mathrm{dS} \cdot \mathrm{m}^{-}$ & $4,0 \mathrm{dS} \cdot \mathrm{m}^{-1}$ & $0,3 \mathrm{dS} \cdot \mathrm{m}^{-1}$ & $4,0 \mathrm{dS} \cdot \mathrm{m}^{-1}$ \\
\hline & \multicolumn{2}{|c|}{$\begin{array}{l}\text { Ci* } \\
\left(\mu \mathrm{mol} \mathrm{m}{ }^{-2} \mathrm{~s}^{-1}\right)\end{array}$} & \multicolumn{2}{|c|}{$\begin{array}{l}\mathrm{A}^{*} \\
\left(\mu \mathrm{mol} \mathrm{m} \mathrm{m}^{-2} \mathrm{~s}^{-1}\right)\end{array}$} & \multicolumn{2}{|l|}{$\mathrm{A} / \mathrm{Ci}^{*}$} \\
\hline FRL & $260 \mathrm{bA}$ & $254 \mathrm{cA}$ & $8.68 \mathrm{bA}$ & $7.58 \mathrm{bA}$ & $0.034 \mathrm{bA}$ & $0.030 \mathrm{bA}$ \\
\hline SCRL & 266 bA & $234 \mathrm{~dB}$ & $11.28 \mathrm{aA}$ & $10.38 \mathrm{aA}$ & $0.042 \mathrm{aA}$ & $0.044 \mathrm{aA}$ \\
\hline VKL & $248 \mathrm{bA}$ & $251 \mathrm{cA}$ & $8.90 \mathrm{bA}$ & $9.49 \mathrm{aA}$ & $0.036 \mathrm{bA}$ & $0.038 \mathrm{aA}$ \\
\hline CSM x SWC - 028 & $287 \mathrm{aA}$ & $290 \mathrm{aA}$ & $4.23 \mathrm{cA}$ & $4.53 \mathrm{cA}$ & $0.015 \mathrm{cA}$ & $0.016 \mathrm{cA}$ \\
\hline CSM x SWC - 033 & $275 \mathrm{aA}$ & $272 \mathrm{bA}$ & $3.11 \mathrm{cA}$ & $3.07 \mathrm{cA}$ & $0.011 \mathrm{cA}$ & $0.011 \mathrm{cA}$ \\
\hline CSM x SWC - 041 & $278 \mathrm{aA}$ & $261 \mathrm{cB}$ & $3.85 \mathrm{cB}$ & $7.58 \mathrm{bA}$ & $0.014 \mathrm{cB}$ & $0.029 \mathrm{bA}$ \\
\hline Genotype & \multicolumn{2}{|c|}{$\begin{array}{l}g s^{* *} \\
\left(\mathrm{~mol} \mathrm{de} \mathrm{H}_{2} \mathrm{O} \mathrm{m}^{-2} \mathrm{~s}^{-1}\right)\end{array}$} & \multicolumn{2}{|c|}{$\begin{array}{l}\mathrm{E}^{* * *} \\
\left(\mathrm{mmol} \text { de } \mathrm{H}_{2} \mathrm{O} \mathrm{m}^{-2} \mathrm{~s}^{-1}\right)\end{array}$} & \multicolumn{2}{|c|}{$\begin{array}{l}\text { EUA* } \\
\left(\mu \mathrm{mol} \mathrm{m} \mathrm{m}^{-2} \mathrm{~s}^{-1}\right) \\
\left(\mathrm{mmol} \mathrm{de}_{2} \mathrm{O} \mathrm{m}^{-2} \mathrm{~s}^{-1}\right)^{-1}\end{array}$} \\
\hline FRL & \multicolumn{2}{|l|}{$0.15 \mathrm{~b}$} & \multicolumn{2}{|l|}{$2.35 \mathrm{a}$} & $3.63 \mathrm{aA}$ & $3.40 \mathrm{aA}$ \\
\hline SCRL & \multicolumn{2}{|l|}{$0.23 \mathrm{a}$} & \multicolumn{2}{|l|}{$2.99 \mathrm{a}$} & $3.58 \mathrm{aA}$ & $3.68 \mathrm{aA}$ \\
\hline VKL & \multicolumn{2}{|l|}{$0.17 \mathrm{~b}$} & \multicolumn{2}{|l|}{$2.68 \mathrm{a}$} & $3.33 \mathrm{aA}$ & $3.55 \mathrm{aA}$ \\
\hline CSM x SWC - 028 & \multicolumn{2}{|l|}{$0.10 \mathrm{~b}$} & \multicolumn{2}{|l|}{$1.76 \mathrm{~b}$} & $2.40 \mathrm{bA}$ & $2.23 \mathrm{bA}$ \\
\hline CSM x SWC - 033 & \multicolumn{2}{|l|}{$0.06 \mathrm{c}$} & \multicolumn{2}{|l|}{$1.20 \mathrm{c}$} & $2.51 \mathrm{bA}$ & $2.69 \mathrm{bA}$ \\
\hline CSM x SWC - 041 & \multicolumn{2}{|l|}{$0.12 b$} & \multicolumn{2}{|l|}{$1.93 \mathrm{~b}$} & $2.12 \mathrm{bB}$ & $4.05 \mathrm{aA}$ \\
\hline
\end{tabular}

$*$ and $* *=$ Interaction genotype $\mathrm{x}$ water salinity and genotype factor significant at 0.05 probability level, respectively. Means followed by different small letters indicate differences between genotypes by Skott-Knott test and capital letters indicate difference between salinity levels by F test at 0.05 probability. FRL - 'Florida Rough lemon' (C. jambhiri), SCRL - 'Santa Cruz Rangpur' lime $(C$. limonia), VKL - Volkamer lemon (Citrus volkameriana), CSM - Common 'Sunki' mandarin (C. sunki) and SWC - 'Swingle' citrumelo (Citrus paradisi $\mathrm{x}$ Poncirus trifoliata).

Regarding the stomatal conductance and the transpiration rate, differences between genotypes were observed. For 'Santa Cruz Rangpur' lime, 'Florida Rough' lemon and 'Volkamer' lemon, the greatest transpiration activities were observed. This means a greater photosynthetic activity and indicates an increased gas exchange activity of these 
genotypes in relation to the other (Table 3). This may also explain their higher growth.

Regarding the study of chlorophyll $a$ fluorescence, an expansion of 32, 28, 24 and $20 \%$ in the initial fluorescence for SCRL, FRL, CSM $x$ SWC - 028 and CSM x SWC - 033, respectively, was observed when they were subjected to the highest salinity level $\left(4.0 \mathrm{dS} \mathrm{m}^{-1}\right)$ compared to the results obtained when subjected to the lowest salinity level $\left(0.3 \mathrm{dS} \mathrm{m}^{-1}\right)$ (Table 4$)$. Knowing that initial fluorescence (Fo) is the loss of light energy by fluorescence of photosystem II (PSII),in which primary acceptors are oxidized, that is, after they remained for a time in the dark, this variable allows determining whether or not the photosynthetic apparatus has the potential to absorb light, losing as little energy as possible as heat. It can thus be said that these genotypes had damage in photosynthetic apparatus, although this did not reflect a significant reduction in gas exchange. Corroborating with this information, Baker and Rosenqust (2004) report that the increase in initial fluorescence reveals a destruction of the PSII reaction center (P680) or a decrease in the transfer capacity of excitation energy from the antenna to the PSII. Thus, the increase in the initial minimum fluorescence due to the effect of salinity may indicate damage to the PSII. However, the damage is not yet sufficient to promote alterations in the gas exchange of such genotypes.

Table 4. Initial fluorescence (Fo), maximum fluorescence $(\mathrm{Fm})$, variable fluorescence $(\mathrm{Fm}-\mathrm{Fo})$ and photosystem II quantum efficiency ( Fv/Fm) for six citrus genotypes grown in two levels of salinity of the water.

\begin{tabular}{|c|c|c|c|c|c|c|}
\hline \multirow{2}{*}{ Genotype } & \multicolumn{2}{|c|}{ Fo (photon)* } & \multirow{2}{*}{$\begin{array}{l}\text { Fm (photon)** } \\
---\end{array}$} & \multirow{2}{*}{ Fm-Fo (photon)** } & \multicolumn{2}{|l|}{$\mathrm{Fv} / \mathrm{Fm} *$} \\
\hline & $0,3 \mathrm{dS} \cdot \mathrm{m}^{-1}$ & $4,0 \mathrm{dS} \cdot \mathrm{m}^{-1}$ & & & $0,3 \mathrm{dS} \cdot \mathrm{m}^{-1}$ & $4,0 \mathrm{dS} \cdot \mathrm{m}^{-1}$ \\
\hline FRL & $419 \mathrm{aB}$ & $536 \mathrm{aA}$ & $2338 \mathrm{a}$ & $1860 \mathrm{a}$ & $0.81 \mathrm{aA}$ & $0.78 \mathrm{aA}$ \\
\hline SCRL & $381 \mathrm{bB}$ & $503 \mathrm{aA}$ & $2220 \mathrm{a}$ & $1778 \mathrm{a}$ & $0.82 \mathrm{aA}$ & $0.78 \mathrm{aA}$ \\
\hline VKL & $435 \mathrm{aA}$ & $450 \mathrm{bA}$ & $2195 \mathrm{a}$ & $1753 \mathrm{a}$ & $0.81 \mathrm{aA}$ & $0.79 \mathrm{aA}$ \\
\hline CSM x SWC - 028 & $387 \mathrm{bB}$ & $480 \mathrm{aA}$ & $1522 \mathrm{~b}$ & $1088 \mathrm{~b}$ & $0.77 \mathrm{aA}$ & $0.64 \mathrm{bB}$ \\
\hline CSM x SWC - 033 & $341 \mathrm{bB}$ & $411 \mathrm{bA}$ & $1898 \mathrm{~b}$ & $1521 \mathrm{a}$ & $0.81 \mathrm{aA}$ & $0.79 \mathrm{aA}$ \\
\hline CSM x SWC - 041 & $467 \mathrm{aA}$ & $424 \mathrm{bA}$ & $1966 \mathrm{a}$ & $1522 \mathrm{a}$ & $0.78 \mathrm{aA}$ & $0.75 \mathrm{aA}$ \\
\hline
\end{tabular}

$*$ and $* *=$ Interaction genotype $\mathrm{x}$ water salinity and genotype factor significant at 0.05 probability level, respectively. Means followed by different small letters indicate differences between genotypes by Skott-Knott test and different capital letters indicate difference between salinity levels by F test at 0.05 probability. FRL - 'Florida Rough lemon' (C. jambhiri), SCRL - 'Santa Cruz Rangpur' lime ( $C$. limonia), VKL - Volkamer lemon (Citrus volkameriana), CSM - Common 'Sunki' mandarin (C. sunki) and SWC - 'Swingle' citrumelo (Citrus paradisi x Poncirus trifoliata).

There were no effects of water salinity on the variable and maximum fluorescence of the genotypes. However, differences were observed among genotypes, with the lowest average observed for CSM x SWC- 028 (Table 4). It is known that maximum fluorescence intensity (Fm) denotes energy loss when the acceptors of PSII reactions centers reached their maximum energy absorption capacity, evidencing the reduced condition of all quinone $(\mathrm{Q})$ because of electrons transferred from the P680 (BAKER; ROSENQVST, 2004; MENDONÇA et al., 2010; SILVA et al., 2014). It is also known that it directly influences variable fluorescence, which is potentially active energy in PSII and reduced activity of chlorophyll $a$. Thus, this may explain the low photosynthetic rates of this genotype, compared to other genotypes.

For the hybrid CSM x SWC- 028, a reduction of $15.5 \%$ in the quantum efficiency of the photosystem II due to an increase in salinity from 0.3 to $4.0 \mathrm{dS} \mathrm{m}^{-1}$ was also observed. According to
Svitsev, Ponnamoreva and Kuznestova (1973), this effect may be related to the increase in the activity of chlorophyllase, an enzyme involved in the removal of the phytol group during the degradation of chlorophyll caused by the stress conditions to which the plant was submitted, since changes in the initial fluorescence of this genotype were also observed (Table 4). For the other genotypes, no changes in the quantum efficiency of the photosystem II were observed, confirming the results observed for gas exchange (Tables 3 and 4).

The study of biomass accumulation revealed reductions of 32.3 and $27.5 \%$ in the root dry matter for 'Santa Cruz Rangpur' lime and 'Volkamer' lemon, respectively, upon comparing the lowest and the highest level of salinity. Despite the reductions observed in these genotypes, they also had the highest root dry matter accumulation compared to the other genotypes (Table 5). Thus, it is believed that the reduction of the root system under salinity conditions favors a lesser absorption of toxic ions, 
thereby avoiding toxicity by specific ions. This is because a greater root growth, besides favoring a higher exploration of the environment in search for nutrients under saline conditions, may also lead to a greater absorption of $\mathrm{Na}^{+}$and $\mathrm{Cl}^{-}$ions until toxic levels and its consequent transport to the shoot, damaging plant growth as a whole (BRITO et al., 2008; FERNANDES et al., 2011; GONZÁLEZ; SYVERTSEN; ETXEBERRIA, 2012; BRITO et al., 2014a; BRITO et al., 2014b; SYVERTSEN; GARCIA-SANCHEZ, 2014).
Salinity did not significantly influence total and shoot dry matter accumulation of citrus genotypes. The 'Volkamer' lemon had the highest accumulation of shoot dry matter $(5.320 \mathrm{~g})$ and total dry matter $(7.580 \mathrm{~g})$ among the genotypes studied (Table 5). This result may be correlated with a higher vegetative growth and a photosynthetic potential observed in this lemon. These attributes were not changed under the highest level of salinity $\left(4.0 \mathrm{dS} \mathrm{m}^{-1}\right)$, being a potential propagation material for growing citrus in areas with salinity problems.

Table 5. Root dry matter (RDM), shoot dry matter (SDM), total dry matter (TDM) and root/shoot ratio (RSR) for six citrus genotypes grown in two levels of salinity of the water.

\begin{tabular}{|c|c|c|c|c|c|c|}
\hline \multirow{2}{*}{ Genotype } & \multicolumn{2}{|l|}{$\mathrm{RDM}^{*}(\mathrm{~g})$} & \multirow{2}{*}{$\mathrm{SDM}^{* *}(\mathrm{~g})$} & \multirow{2}{*}{ TDM** $(\mathrm{g})$} & \multicolumn{2}{|l|}{$\mathrm{RSR}^{*}$} \\
\hline & $0.3 \mathrm{dS} . \mathrm{m}^{-1}$ & $4.0 \mathrm{dS} . \mathrm{m}^{-1}$ & & & $0.3 \mathrm{dS} . \mathrm{m}^{-1}$ & $4.0 \mathrm{dS} . \mathrm{m}^{-1}$ \\
\hline FRL & $1.100 \mathrm{bA}$ & $1.085 \mathrm{aA}$ & $2.953 \mathrm{~b}$ & $4.046 \mathrm{~b}$ & $0.389 \mathrm{aA}$ & $0.387 \mathrm{aA}$ \\
\hline SCRL & $1.977 \mathrm{aA}$ & $1.339 \mathrm{aB}$ & $3.911 \mathrm{~b}$ & $5.520 \mathrm{~b}$ & $0.455 \mathrm{aA}$ & $0.307 \mathrm{aA}$ \\
\hline VKL & $2.080 \mathrm{aA}$ & $1.507 \mathrm{aB}$ & $5.320 \mathrm{a}$ & $7.580 \mathrm{a}$ & $0.387 \mathrm{aA}$ & $0.265 \mathrm{aA}$ \\
\hline CSM x SWC - 028 & $0.026 \mathrm{cA}$ & $0.084 \mathrm{bA}$ & $0.218 \mathrm{c}$ & $0.274 \mathrm{c}$ & $0.183 \mathrm{bA}$ & $0.174 \mathrm{bA}$ \\
\hline CSM x SWC - 033 & $0.040 \mathrm{cA}$ & $0.063 \mathrm{bA}$ & $0.184 \mathrm{c}$ & $0.236 \mathrm{c}$ & $0.227 \mathrm{bA}$ & $0.336 \mathrm{aA}$ \\
\hline CSM x SWC - 041 & $0.131 \mathrm{cA}$ & $0.081 \mathrm{bA}$ & $0.323 \mathrm{c}$ & $0.580 \mathrm{c}$ & $0.405 \mathrm{aA}$ & $0.250 \mathrm{aB}$ \\
\hline
\end{tabular}

$*$ and $* *=$ Interaction genotype $\mathrm{x}$ water salinity and genotype factor significant at 0.05 probability level, respectively. Means followed by different small letters indicate differences between rootstocks by Skott Knott test and different capital letters indicate difference between salinity levels by F test at $5 \%$ probability. FRL - 'Florida Rough lemon' $(C$. jambhiri), SCRL - 'Santa Cruz Rangpur' lime $(C$. limonia), VKL - Volkamer lemon (Citrus volkameriana), CSM - Common 'Sunki' mandarin (C. sunki) and SWC - 'Swingle' citrumelo (Citrus paradisi x Poncirus trifoliata).

A reduction in the root/shoot ratio of the genotype CSM x SWC- 041 was observed when subjected to salt stress (Table 5), which may be related to a reduced root growth, since there were no effects of salinity on shoot dry mass. This behavior confirms what was observed for 'Santa Cruz Rangpur' lime and 'Volkamer' lemon, in which a reduction in root dry matter accumulation (RDM) was also observed. It can be inferred that the reduction of the root system under salt stress is expressed as a tolerance mechanism of the genotypes and consequently the absorption of toxic ions by the plant. This can be confirmed observing the performance of the photosynthetic activity of these three genotypes.

\section{CONCLUSIONS}

Salt stress influenced growth and/or physiology of all studied genotypes.
Salt stress did not influence the chlorophyll $a$ fluorescence of 'Volkamer' lemon and CSM x SWC - 041, indicating no damage to their photosynthetic apparatus.

The 'Volkamer' lemon, CSM x SWC- 041, 'Santa Cruz Rangpur' lime and 'Florida Rough' lemon have better physiological indexes, even under saline conditions;

Common 'Sunki' mandarin with 'Swingle' citrumelo hybrids have the lowest growth rates;

'Florida Rough' lemon, 'Santa Cruz Rangpur' lime and the hybrid CSM x SWC- 041 are the most tolerant to salinity based on growth rates.

\section{ACKNOWLEDGEMENTS}

To CNPq - Brazilian National Council of Scientific and Technological Development, and EMBRAPA Cassava \& Fruit.

RESUMO: A fim de estudar o crescimento e a fisiologia de porta-enxertos de citros sob irrigação com água salina, durante a formação de porta-enxertos, realizou-se um ensaio fatorial 2 × 6 , correspondente a dois níveis de salinidade da solução nutritiva: 0,3 e $4,0 \mathrm{dS} \mathrm{m}^{-1}$ e seis genótipos fornecidos pelo Programa de Melhoramento de Citros da 
Embrapa Mandioca \& Fruticultura-PMGC, distribuídos em delineamento em blocos casualizados com três repetições. Os genótipos foram: 1. 'limoeiro Cravo Santa Cruz' (LCRSTC) (Citrus limonia Osbeck), 2. 'limoeiro Rugoso da Flórida' (LRF) (Citrus jambhiri Lush.), 3. 'limoeiro Volkameriano' (LVK) (C. Volkameriana V. Ten. \& Pasq.), 4. CSM x SWC028, 5. CSM x SWC- 033 e 6. CSM x SWC-041, os últimos três híbridos de tangerineira 'Sunki' comum (CSM) [C. sunki (Hayata) hort. Ex Tanaka] com citrumelo 'Swingle' (SWC) [C. Paradisi Macfad. x Poncirus trifoliata (L.) Raf.] Plantas de origem nucelar desses genótipos foram cultivadas em sistema hidropônico alternativo, utilizando vasos Leonard. A aplicação de solução nutritiva feita com água salina iniciou-se a partir de 90 dias após a semeadura até 120 dias, quando foram avaliados os parâmetros de crescimento e fisiologia das plantas. O estresse salino influenciou o crescimento e os parâmetros fisiológicos em todos os genótipos. O estresse salino não influenciou a fluorescência da clorofila a nos genótipos VKL e CSM x SWC-041, indicando não haver danos ao aparelho fotossintético. O CSM x SWC-041, 'limoeiro Cravo Santa Cruz', 'limoeiro Rugoso da Flórida' e 'limoeiro Volkameriano' são os genótipos mais tolerantes à salinidade com base na taxa de crescimento.

PALAVRAS-CHAVE: Citrus spp. Fluorescência da clorofila. Taxa de crescimento. Trocas gasosas. Salinidade.

\section{REFERENCES}

AL-YASSIN, A. Influence of salinity on citrus: a review paper. Journal of Central European Agriculture, Jordan, v.5, n. 4, p.263-272, Apr. 2004.

BAKER, N. R.; ROSENQVST, E. Applications of chlorophyll fluorescence can improve crop production strategies: an examination of future possibilities. Journal of Experimental Botany, Oxford, v. 55, n. 403, p. 1607-1621, Dez. 2004. http://dx.doi.org/10.1093/jxb/erh196

BALAL, R. M.; KHAN, M. M.; SHAHID, M. A.; MATTSON, N. S.; ABBAS, T.; ASHFAQ, M.; GARCIASANCHEZ, F.; GHAZANFER, U.; GIMENO, V.; IQBAL, Z. Comparative studies on the physiobiochemical, enzymatic, and ionic modifications in salt-tolerant and salt-sensitive citrus rootstocks under $\mathrm{NaCl}$ stress. Journal American Society Horticultural Science, Alexandria, v. 137, n. 2, p. 86-95, Fev. 2012.

BENINCASA, M. M. P. Análise de crescimento de plantas: noções básicas. Jaboticabal: Funep, 2003.41 p.

BRITO, M. E. B.; BRITO, K. S. A.; FERNANDES, P. D.; GHEYI, H. R.; SUASSUNA, J. F.; SOARES FILHO, W. S.; MELO, A. S.; XAVIER, D. A. Growth of ungrafted and grafted citrus rootstocks under saline water irrigation. African Journal of Agricultural Research, v. 9, n. 50, p. 3600-3609, Nov. 2014b. https://doi.org/10.5897/2014.9039

BRITO, M. E. B.; FERNANDES, P. D.; GHEYI, H. R.; MELO, A. S.; SOARES FILHO,W. S.; SANTOS, R. T. Sensibilidade à salinidade de híbridos trifoliados e outros porta-enxertos de citros. Revista Caatinga, Mossoró, v. 27, n. 1, p. 17-27, Jan. 2014a.

BRITO, M. E. B.; FERNANDES, P. D.; GHEYI, H. R.; MELO, A. S.; CARDOSO, J. A. F.; SOARES FILHO, W. S. Sensibilidade de variedades e híbridos de citrange à salinidade na formação de porta-enxertos. Revista Brasileira de Ciências Agrárias, Recife, v. 3, n. 4, p 343-353, Dez. 2008. http://dx.doi.org/10.5039/agraria.v3i4a364.

FERNANDES, P. D.; BRITO, M. E. B.; GHEYI, H. R.; SOARES FILHO, W. S.; MELO, A. S.; CARNEIRO, P. T. Crescimento de híbridos e variedades porta-enxerto de citros sob salinidade. Acta Scientiarum Agronomy, Maringá, v. 33, n. 2, p. 259-267, Fev. 2011. http://dx.doi.org/10.4025/actasciagron.v33i2.5582.

FERREIRA, D. F. Sisvar: a computerstatisticalanalysis system. Ciência e Agrotecnologia, Lavras, v. 35, n. 6, p. 1039-1042, Jun. 2011. http://dx.doi.org/10.1590/S1413-70542011000600001. 
FRANCO, D.; CAVALCANTE, I. H. L.; OLIVEIRA, I. V. M.; MARTINS, A. B. G. Avaliação de substratos no desenvolvimento inicial de seis porta-enxertos de citros. Laranja, Cordeirópolis, v. 28, n. 1-2, p. 61-70, Dez. 2007.

GONZÁLEZ, P.; SYVERTSEN, J. P.; ETXEBERRIA, E. Sodium distribution in salt-stressed citrus rootstock seedlings. HortScience, Alexandria, v. 47, n. 10, p. 1504-1511, Oct. 2012.

HOAGLAND, D. R.; ARNON, D. I. The water-culture method for growing plants without soil. Berkeley, California Agricultural Experiment Station, California, 1950. 32p. (Circular, 347).

IBGE. Instituto Brasileiro de Geografia e Estatística. Indicadores IBGE. Disponível em: $<\mathrm{http} / / /$ www.sidra.ibge.gov.br/bda/tabela/listabl.asp?z=t\&o=1\&i=P\&e=1\&c=1613>. Acesso em: 25 Agosto. 2016.

LÓPEZ-CLIMENT, M. F.; ARBONA, V.; PÉREZ-CLEMENTE, R. M.; GÓMEZ-CADENAS, A. Effects of cadmium on gas exchange and phytohormone contents in citrus. Biologia Plantarum, Praga, v. 55, n. 1, p. 187-190, Jan. 2011. http://dx.doi.org10.1007/s10535-011-0028-4

MACHADO, E. C.; SCHMIDT, P. T.; MEDINA, C. L.; RIBEIRO, R. V. Respostas da fotossíntese de três espécies de citros a fatores ambientais. Pesquisa Agropecuária Brasileira, Brasília, v. 40, n. 12, p. 1161-1170, Dez. 2005. http://dx.doi.org/10.1590/S0100-204X2005001200002

MENDONÇA, A. V. R.; CARNEIRO, J. G. A.; FREITAS, T. A. S.; BARROSO, D. G. Características fisiológicas de mudas de Eucalyptusspp submetidas a estresse salino. Ciência Florestal, Santa Maria, v. 20, n. 2, p. 255-267, Fev. 2010. http://dx.doi.org/10.5902/198050981850

NASCIMENTO, A. K. S.; FERNANDES, P. D.; SUASSUNA, J. F.; OLIVEIRA, A. C. M.; SOUSA, M. S. S.; AZEVEDO, J. G. N. Tolerância de genótipos de citros ao estresse hídrico na fase de porta-enxerto. Irriga, Botucatu, Edição Especial, p. 438-452, Dez. 2012. http://dx.doi.org/10.15809/irriga.2012v1n01p438

POMPEU JUNIOR, J.; BLUMER, S.; RESENDE, M. D. Avaliação genética de seleções e híbridos de limões Cravo, Volkameriano e Rugoso como porta-enxertos para laranjeiras valência na presença da morte súbita dos citros. Revista Brasileira de Fruticultura, Jaboticabal, v. 35, n. 1, p. 199-209, Jan. 2013. http://dx.doi.org/10.1590/S0100-29452013000100023.

REZENDE, C. F. A.; FERNANDES, E. P.; SILVA, M. F.; LEANDRO, W. M. Crescimento e acúmulo de nutrientes em mudas cítricas cultivadas em ambiente protegido. Bioscience Journal, Uberlândia, v. 26, n. 3, p. 367-375, Jun. 2010.

RODRÍGUEZ-GAMIR, J.; ANCILlO, G.; LEGAZ, F.; PRIMO-MILlO, E.; FORNER-GINER, M. A. Influence of salinity on pip gene expression in citrus roots and its relation-ship with root hydraulic conductance, transpiration and chloride exclusion from leaves. Environmental and Experimental Botany, Paris, v. 78, n. 5, p. 163-166, May. 2012. http://dx.doi.org/10.1016/j.envexpbot.2011.12.027

SÁ, F. V. S.; BRITO, M. E. B.; SILVA, L. A.; MOREIRA, R. C. L.; FERNANDES, P. D.; FIGUEIREDO, L. C. Fisiologia da percepção do estresse salino em híbridos de tangerineira -Sunki Comum sob solução hidropônica salinizada. Comunicata Scientiae, Bom Jesus, v. 6, n. 4, p. 463-470, Dez. 2015. http://dx.doi.org/10.14295/cs.v6i4.1121

SCHÄFERI, G.; SOUZA, P. V. D.; MACIEL, H. S.; FOCHESATO, M. L. Aproveitamento de plântulas de porta-enxertos cítrico oriundas do desbaste e seu desenvolvimento vegetativo inicial. Ciência Rural, Santa Maria, v. 38, n. 6, p. 1558-1563, Jun. 2008. http://dx.doi.org/10.1590/S0103-84782008000600011 
SHIMAZAKI, K.; DOI, M.; ASSMANN, S. M.; KINOSHITA, T. Light regulation of stomatal movement. Annual Review of Plant Biology, Gainesville, v. 58, n. 1, p. 219-247, Jan. 2007. http://dx.doi.org/10.1146/annurev.arplant.57.032905.105434

SILVA, F. V.; SOARES, F. A. L.; GHEYI, H. R.; TRAVASSOS, K. D.; SUASSUNA, J. F.; CARDOSO, J. A. F. Produção de citros irrigados com água moderadamente salina. Irriga, Botucatu, Edição especial, p. 396 407, Dez. 2012. http://dx.doi.org/10.15809/irriga.2012v1n01p396

SILVA, L. D. A.; BRITO, M. E.; SÁ, F. V. S.; MOREIRA, R. C.; SOARES FILHO, W. S.; FERNANDES, P. D. Mecanismos fisiológicos em híbridos de citros sob estresse salino em cultivo hidropônico. Revista Brasileira de Engenharia Agrícola e Ambiental, Campina Grande, v. 18, (Suplemento) p. 1-7, Dez. 2014. http://dx.doi.org/10.1590/1807-1929/agriambi.v18nsupps1-s7.

SINGH, A.; SAINI, M. L.; BEHL, R. K. Screening of citrus rootstocks for salt tolerance in semi-arid climates A review. Tropics, Japan, v. 13, n. 1, p. 53-66, Jan. 2003. http://doi.org/10.3759/tropics.13.53

SOUZA, A. D. G.; FAQUIN, V.; CHALFUN, N. N.; SOUZA, A. A. Produção de mudas de tangerineira 'Ponkan' em sistema hidropônico. Revista Ciência Agronômica, Fortaleza, v. 44, n. 4, p. 902-909, Dez. 2013. http://dx.doi.org/10.1590/S1806-66902013000400029.

STUCHI, E. S.; GIRARDI, E. A. Adensamento de plantio deve ser o quarto elemento no manejo do HLB. Citricultura Atual, Cordeirópolis, v. 16, n. 81, p. 12 - 16, Jan. 2011.

SVITSEV, M. V.; PONNAMOREVA, S. A.; KUZNESTOVA, E. A. Effect of salinization and herbicides on chlorophyllase activity in tomato leaves. Fiziologiya Rastenii, Moskva, v. 20, n. 1, p. 62-65, Jan. 1973

SYVERTSEN, J. P.; GARCIA-SANCHEZ, F. Multiple abiotic stresses occurring with salinity stress in citrus. Environmental and Experimental Botany, Paris, v. 103, n. 7, p. 128-137, Jul. 2014. http://dx.doi.org/10.1016/j.envexpbot.2013.09.015

TAIZ, L.; ZEIGER, E. Fisiologia vegetal. 5.ed. Porto Alegre: Artmed, 918 p. 2013. 